\title{
The Influence of Training, Motivation, and Work Ethics on the Internal Communication and Their Impact on the Employee Performance
}

\author{
Endang Saefuddin Mubarok \\ Faculty of Economics - Jakarta Islamic University, Jakarta, Indonesia \\ Juwiko Darmawan \\ Faculty of Economics - Jakarta Islamic University, Jakarta, Indonesia
}

\begin{abstract}
This study aims to identify the effect of training, motivation, and work ethics on internal communication and its impact on employee performance. The design of this research is descriptive and quantitative explanative, using multivariate analysis methods. The sample for this study was 323 respondents selected using the proportional sampling method. Data collection was carried out using a questionnaire. Research data were analyzed using structural equation modeling (SEM) with partial least square (PLS) approach. The results showed that training had a significant effect on communication, but not significantly on performance. Motivation has a significant effect on internal communication and employee performance. Work ethics has a significant effect on communication, but not significantly on performance. Meanwhile, internal communication has a significant influence on performance. Furthermore, training, motivation, work ethic, and internal communication simultaneously have a significant effect on performance. Simultaneous training, motivation, and work ethic also significantly influence performance.
\end{abstract}

Keywords: Training, Motivation, Work Ethics, Internal Communication, Performance

DOI: $10.7176 / \mathrm{EJBM} / 11-24-10$

Publication date: August $31^{\text {st }} 2019$

\section{Introduction}

Since the 1990s, there has been a global change with a specific characteristic, which unpredictable, surprising, and giving rise to numerous conflicts within organizations. The competitive situation has become tighter from time to time (Berkema, et al., 2002) and has raised the competition to become the most superior. The characteristic of the competition has fundamentally changed from a competition into an adversary. This competition can only be won by those who have high level of competitiveness. This competitiveness is defined as the ability to compete in terms of speed and innovation. Therefore, the generation living in the global era is forced to have an excellent performance (Guerra, 2008).

The competitiveness of an organization can only be achieved with excellent human resources, so the current competition is called as the competition of human resources and no longer a competition of technology. Technology is relatively easy to achieve as long as there is enough money to buy the technology. However, to build human resources who are able to take advantage and develop technology is not an easy task. Nowadays, the issue faced by any organization is on how to sustainably improve knowledge from its human resources, according to the challenges faced by the organization. Therefore, the efforts to improve knowledge as a learning process have become an important and deciding factor for the excellence of the human resources. It means that there needs to be an effort to make the learning process as part of the work behavior (Bahaudin, 2000). Without a learning culture, an individual cannot possibly have a learning organization and without a learning organization it is impossible for an organization to improve the excellence of its human resources.

The environment faced by the human resources management is basically a challenge in the rising change and its broad problems. The conclusions of the experts' studies (Mubarok, 2017) show that the challenges faced by the human resources management cover the following: (1) Economics and technological development; (2) the availability and quality of workforce; (3) population and its problems; and (4) organization restructuration. The challenge in managing human resources has experienced a fundamental change, in which in life, we continue to learn. The adage that life is a learning process has become an expectation. In learning, there is a part of the human's body that is mostly related to the learning process - the brains and the heart. The issue is on how we can have an optimum and balanced management of our brains and heart. Organizing such learning is believed to improve knowledge and values of each member of an organization, to have an effective communication, to support motivation, to grow work ethics, and to develop work innovation to win the competition.

The parameter that can be used to measure the learning process where human resources have a degree of competitiveness (Kasali, 2010) is when they are not only well-educated, but also cultivated. This relates to a formed muscle memory through training. They who are only building knowledge through their brains will only 
be able to see everything through the lens of their own brain memory. Such human resources will only be able to build a concept, but they will face a huge obstacle when they have to actualize their concept. A combination between brain memory and muscle memory is therefore needed to produce human resources who have big ideas supported by creative and innovative actions. From there on the impetus of human resources with excellent competitiveness is made possible.

In the perspective of defense management, learning as human resources development will have an influence on the framework of defense power. Therefore, a new framework on the level of policy or operational in the form of human resources management is the assets capable of dynamic development based on their strategic environment. This new paradigm places the element of human as no longer an object, but to serve more as the subject of human resources in the field of defense, so they can perform maximally in the process of defense management (Midhio, 2016).

The transformation of human resources management in the field of defense is closely related to the transformation process of the universal defense system, which began with the reformation process of the Armed Forces starting from 1998. The transformation of the defense system is still leaving some agenda, such as the personal policy aspects, education and training, defense economy, technology- and innovation-based, posture and basic training or orders of battle, issues of doctrine, and operational. Therefore, the efforts to develop and grow an organization and the business of human resources are important and deciding assets (Midhio, 2016). Human is no longer seen as the factor of production, but an asset who have a number of added values if the individual is used and precisely allocated for the growth of an organization (Midhio, 2016).

In line with the above, the Ministry of Defense as the Government Executive in charge of defense is expected to keep on striving for its employee/personnel to fit for the organization. To fulfil the expectation, the efforts made are implemented in the following programs: (1) Education and Training Program on defense management-derived into twenty-two programs; (2) Education and Training Program on language, which covers: English Intensive Course, Non-English Language Course, and English workshop for strategic communication skills; and (3) Education and training program defense functional technique covering, which covers: education and training skilled auditor development function, technical administration for formatting rank and other ranks on its level, workshop, and education and training for training of trainer.

An organization is established for a cause, which is expected to achieve. The achievement on the objective of an organization shows the results of the work made in a series of activities. To guarantee for an achievable expected results, the activities within an organization has to be well-organized. This study is aimed at performing an effort of analysis, data and information collection related to the variables of training, motivation, work ethics, internal communication, and employee performance.

\section{Literature Review}

\subsection{Training}

Training can be referred to as a planned and systematic effort to develop knowledge and mentality through learning from experience; to provide knowledge and skills, and instill attitudes needed to achieve specific performance (Buckley, 2009). Training can also be interpreted as a systematic approach that impacts on the development of knowledge, skills and attitudes to increase the effectiveness of individuals, groups and organizations (Aguinis and Kraiger, 2009). Training is a short-term effort to improve performance (Rothwell and Kazanas, 2003). Training is basically a systematic learning effort to improve skills and attitudes to achieve better performance. According to Noe et al. (2010), training is aimed at increasing the knowledge and values of organizational members, helping organizational members to have basic skills and knowledge, helping organizational members to do their work effectively, and promoting organizations in developing innovation, creativity, and learning for members. In addition, training is aimed at motivating organizational member readiness to deal with changes in work, to prepare organizational members to work more effectively, and to create an appropriate work atmosphere through effective communication.

In achieving the training objectives, there are a number of aspects involved, namely curriculum, duration of education, teacher, trainee, learning methods and processes, library, and other infrastructure. Meanwhile, in practice, there are a number of key considerations that must be taken into account in the implementation of training: trainees, individuals who teach in training, the media used in the learning process, the level of learning held, the principles of learning used, and where training is held (Rivai and Sagala, 2012). Training is considered effective if the training can answer the needs and provide added value to the organization (Buckley and Caple, 2009). Snaks and Haccoun (2010: 18-22) explained that the effectiveness of training can be seen based on the following things: results of needs analysis, design and delivery, and evaluation of training. Needs analysis includes organizational needs, job descriptions, and analysis of trained personnel. Design analysis consists of the objectives, methods, and values that are implemented. In order for training to be in line with business planning, the transfer of knowledge and skills must be designed and implemented properly to achieve optimal results. The success of the training can be seen through seeing the reaction, learning, behavior, and results (Kickpatricks, 


\subsection{Motivation}

Motivation is a process that stimulates individuals to get something they want. Motivation is related to the willingness to work hard to achieve organizational goals that are stimulated by incentives and something that can be considered as incentives can help them achieve their goals. Motivation is a process that helps in determining the intensity, direction, and perseverance for individual efforts in achieving their targets (Kumar and Rosse, 2010). Robbins (2003) defines work motivation as a willingness to achieve organizational goals. There are three main elements in defining motivation: intensity, direction, and duration. Intensity is related to how hard someone is trying to do his job. Direction relates to channeling efforts to produce performance that is beneficial to individuals and organizations. Duration shows persistence and consistency in making efforts according to the target organization for a long period of time. In the motivational history literature, money has become a motivating factor for someone to work. However, motivation is not only related to money, but also related to social situations.

\subsection{Work ethics}

Work ethics are human character and habits or human attention and morality in doing something that has become a routine of life. Work ethic is also referred to as the basic pattern of attitudes that affect the behavior of a person, group, society that takes place consistently and continuously. In addition, the literature defines work ethics as the overall characteristics of usage, ideas, standards, and codes that make one individual different from other individuals. Work ethics refers to attitudes and views about work, characteristics, and ways of working a person, a group of people or a nation. Work ethics are characteristics and habits related to work, which are shown from a person's basic view of life. The word 'ethics' has a broader meaning, not only as a spirit of community life that comes solely from cultural traditions, but has become more dynamic. Sinamo (2009) has defined ethics as the characteristic spirit of a culture, era, or community that is manifested in its attitudes and aspirations or as a guideline for a person's beliefs, groups or institutions. Further, Sinamo (2009) formulates eight paradigms which cover: work is a blessing, work is a mandate, work as a devotion, work as a calling, work as a self-actualization, work as an art, and work as honor, and work as a service.

2.4 Communication

In a traditional literature review, it is shown that communication and organizational success is highly related. Many researchers suggest that management is communication. Organizational communication is more than what people usually do. Organizational communication is a discipline that takes into account a number of legal and beneficial directions. Pace and Faules (2000) define that communication is the creation of message or display and message interpretation or a show. The only important message in communicating is that message comes from the process of making meaning. Internal communication is a form of formal or informal communication which is internally performed on all levels of the organization (Kalla, 2006). Internal communication is an exchange of information and ideas performed in an organization (Bovee and Thill, 2000). According to Curtis et al., (2000), there are several reasons why communication occurs in an organization: giving and receiving information, influencing others, stimulate interest, reducing friction, and empowering the society to perform their task or to educate behavior. If an employee is unaware of the objectives of the company and is unaware that they are a part of that achievement, and they are unable to receive feedback related to their work, then it is possible that they have lost their motivation and interest. This becomes an urgent reason for internal communication within an organization. A number of results from numerous studies show that a company with an effective communication strategy will be more successful than those with poor communication.

2.5 Performance

Performance is the result of work that is closely related to organizational and consumer goals, and contributes to the economy (Armstrong and Baron, 1998). Performance shows a record of the results of the work function in a certain period of time, the results can be measured, can be compared with the targets assigned (Mathis and Jackson, 2004). In other words, performance shows the process of doing the work needed and the results that come from it, what has been done, and how to do it in a certain period of time. Good performance management will benefit employees and organizations in the form of improved performance, promoting productivity, developing personality, a basis for development and training programs, a basis for compensation decisions, and employees can express their feelings. For performance management to provide benefits, performance management must be based on management principles, pay attention to supporting factors, and take periodic measurements. According to Robbins (2003), the principles of good performance management are as follows: organizing strategic planning, taking measurements, improving sustainable performance, developing, developing work culture, and consensus, cooperation, and inter-directional communication. 


\section{Research Methodology}

3.1 Research design

The research design used in this study is descriptive and explanative quantitative with a multivariate analysis method. The research sample is 323 respondents with a proportional sampling method. The data collection was done through the instrument of questionnaire and analyzed with structural equation model (SEM) and partial least square (PLS) approach. The model is used for a limited sample and a non-restrictive data assumption (Hair, et al., 1998)

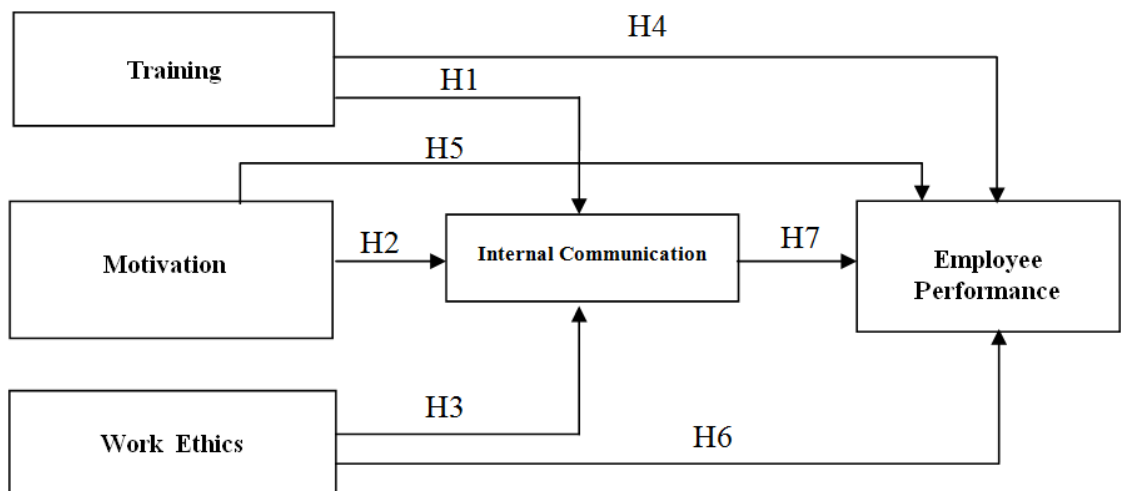

\subsection{Hypotheses development and research model}

Based on the conceptual framework, this study proposes the following seven hypotheses.

Hypothesis 1

Training has a positive and significant direct effect on internal communication skills

Hypothesis 2

Motivation has a positive and significant direct effect on internal communication skills

Hypothesis 3

Work ethics has a positive and significant direct effect on internal communication skills

Hypothesis 4

Training has a positive and significant direct effect on employee performance

Hypothesis 5

Motivation has a positive and significant direct effect on employee performance

Hypothesis 6

Work ethic has a positive and significant direct effect on employee performance

Hypothesis 7

Communication has a positive and significant direct effect on employee performance

\section{Results and Discussion}

\subsection{Measurement model}

In the SEM-PLS, factor loading value is used as the measurement model presenting the valid indicators, and is used to measure the existing construct. An indicator is said to be convergent validity, if the loading value and average variance extracted (AVE) value are higher than 0.5. Also, an indicator is said to be reliable if the composite reliability (CR) and Cronbach's Alpha is higher than 0.7. Table 1 shows those values.

Table 1

AVE Value, Composite Reliability, and Cronbach's Alpha

\begin{tabular}{|l|c|c|c|}
\hline & AVE & $\begin{array}{c}\text { Composite } \\
\text { Reliability }\end{array}$ & $\begin{array}{c}\text { Cronbach's } \\
\text { Alpha }\end{array}$ \\
\hline Training & 0.64 & 0.84 & 0.72 \\
\hline Motivation & 0.56 & 0.86 & 0.80 \\
\hline Work Ethics & 0.62 & 0.89 & 0.84 \\
\hline Communication & 0.60 & 0.91 & 0.89 \\
\hline Performance & 0.58 & 0.91 & 0.89 \\
\hline
\end{tabular}

\subsection{Structural model}

The discriminant validity testing from construct is done by using cross-loadings (Vinzi et al., 2010). The cross- 
loadings value is the correlation between each construct with an item from each construct. The cross-loadings value is resulted from calculating the correlation between the score component of each item within the model. The construct correlation of an item is compared the item of another construct. If construct indicator correlation has a higher score than an indicator correlation, then the value of the construct is said to have high discriminant validity. From the calculation, it shows that the output of the Smart PLS for cross loading construct of each item on its construct is higher than on the cross loading value with another construct. Therefore, from the result of the cross loading analysis shows that there is no problem of discriminant validity. Discriminant validity can be tested by comparing the AVE square with the correlation value between construct. The result of the testing is shown on Table 2. Table 4 shows that the value of the square root from the AVE is higher than the correlation of each construct, so it is said that there is no problem with discriminant validity.

Table 2

The results of discriminant validity test

\begin{tabular}{|l|c|c|c|c|c|}
\hline & Training & Motivation & $\begin{array}{c}\text { Work } \\
\text { ethics }\end{array}$ & $\begin{array}{c}\text { Internal } \\
\text { communication }\end{array}$ & $\begin{array}{c}\text { Employee } \\
\text { performance }\end{array}$ \\
\hline Training & $\mathbf{0 . 8 0 2 1}$ & & & & \\
\hline Motivation & 0.4392 & $\mathbf{0 . 7 5 3 0}$ & & & \\
\hline Work ethics & 0.3241 & 0.5039 & $\mathbf{0 . 7 8 8 6}$ & & \\
\hline $\begin{array}{l}\text { Internal } \\
\text { communication }\end{array}$ & 0.4343 & 0.5734 & 0.4921 & $\mathbf{0 . 7 7 8 4}$ & \\
\hline $\begin{array}{l}\text { Employee } \\
\text { performance }\end{array}$ & 0.4217 & 0.5659 & 0.4756 & 0.6850 & $\mathbf{0 . 7 6 7 3}$ \\
\hline
\end{tabular}

4.3 Hypothesis testing

As discussed above, this study proposes seven hypotheses. Table 4 shows the results of the relationship between constructs in each of these hypotheses.

Table 4

The results of hypotheses testing

\begin{tabular}{|l|c|c|}
\hline Variable relationship & Regression wight $(\beta)$ & Description \\
\hline Training and internal communication & 0.194 & Significant at $\alpha=0.05$ \\
\hline Training and employee performance & 0.092 & Not significant \\
\hline Motivation and internal communication & 0.364 & Significant at $\alpha=0.01$ \\
\hline Motivation and employee performance & 0.194 & Significant at $\alpha=0.05$ \\
\hline Work ethics and internal communication & 0.245 & Significant at $\alpha=0.01$ \\
\hline Work ethics and employee performance & 0.112 & Not significant \\
\hline Communication and employee performance & 0.478 & Significant at $\alpha=0.01$ \\
\hline
\end{tabular}

The influence of training on internal communication

The results indicated that training significantly affected internal communication $(\beta=0.195 ; \mathrm{p}<0.05)$. This finding supports the hypothesis that training conducted by the Ministry of Defense is able to build quality and internal communication skills. In other words, the higher the quality of the training, the better the quality and internal communication skills of the trainees. Therefore, the quality of training in accordance with the challenges of change is the main hope for the success of the Ministry of Defense. The findings of this study indicate that training is one of the factors that influence the quality of internal communication. In government organizations, especially the Ministry of Defense, training is one of the factors needed to build employee communication skills, so that they can contribute positively in achieving the agency's vision, mission and goals. This finding is in line with previous studies which show that training that matches the challenges of change has a significant influence on communication. This study emphasizes the importance of training variables in improving communication skills of individuals, groups, or organizations.

The influence of motivation on the internal communication

The analysis showed that motivation significantly affected $(\beta=0.34 ; p<0.05)$. This finding supports the hypothesis that motivation has a significant effect on internal communication. This finding shows that the motivation built by the Ministry of Defense can support the quality and ability of employees' internal communication. In this case, the higher the motivation of employees, the more the quality and ability of internal communication increases. Therefore, high motivation, directed, and consistent is the answer to the challenges of 
change faced by employees or organizations. Motivation factors have been shown to have a significant impact on internal communication skills. In government organizations, especially the Ministry of Defense, motivation is a determining factor for building employee communication skills. Therefore, the contents of the information sent and received by the parties involved can be maintained as a whole. Furthermore, internal communication can also make a positive contribution to the problems faced by the organization. This finding is in line with previous research which has proven that motivation has a significant effect on internal communication skills. This research confirms the importance of motivation in improving internal communication skills.

The influence of work ethics on internal communication

The analysis showed that work ethics had a significant effect on internal communication $(\beta=0.245 ; p<0.05)$. This finding supports the hypothesis that work ethics has a significant effect on internal communication skills. This means that the work ethic developed by the Ministry of Defense can support the quality and internal communication skills of employees. In other words, the stronger the work ethics of employees, the more the quality and ability of internal communication increases. The findings of this study indicate that work ethics can function as a factor determining internal communication skills. In government organizations, especially the Ministry of Defense, work ethics is an important factor for achieving quality internal communication skills. Therefore, enthusiasm and awareness in communication must be maintained. In addition, a sustainable work ethic will also maintain the quality of internal communication. This finding is in line with previous research that work ethic has a significant influence on the quality of internal communication. This research confirms the importance of work ethics variables in improving communication skills of individuals, groups, or organizations. The Influence of training on employee performance

Research findings confirm that training does not have a significant effect on employee performance $(\beta=0.092$; $\mathrm{p}>0.10$ ). This finding does not support the hypothesis that training has a significant effect on employee performance. This shows that any training program does not have a significant direct effect on employee performance. This means that the implementation of the training program can only have a direct influence on the ability of internal communication, which in turn will improve employee performance. The results of this study are not in line with the results of previous studies which stated that training has a significant direct effect on employee performance. This study confirms that the relationship between training and employee performance is mediated by other variables.

The influence of motivation on performance

The results of the analysis indicate that motivation has a significant effect on employee performance $(\beta=0.195$; $\mathrm{p}<0.05)$. This finding supports the hypothesis that motivation has a significant effect on employee performance. In other words, the better the Ministry of Defense builds employee motivation, the better the employee's performance will be. This means that the better the motivation, the better the performance of employees in carrying out their every task. Motivation is one of the factors that can affect the level of employee performance. Therefore, this variable is a factor that must be improved and supported to improve employee performance. The findings of this study are in line with previous research which proves that motivation has a significant effect on employee performance.

The influence of work ethics on performance

Research findings indicate that work ethics do not have a significant direct effect on employee performance (beta $=0.113 ; \mathrm{p}<0.05)$. This finding does not support the hypothesis that work ethics has a significant direct effect on employee performance. These findings indicate that organizations need to make various efforts on an ongoing basis to foster work ethics in order to improve employee performance. The results show that the impact of work ethics on employee performance is mediated by internal communication skills. This condition is not in line with the results of several previous studies which stated that work ethic has a significant direct effect on employee performance. However, the findings of this study are also supported by several other studies which found that work ethic does not have a significant effect on employee performance.

The Influence of internal communication on performance

The analysis shows that internal communication has a significant direct effect on employee performance (beta $=$ $0.478 ; \mathrm{p}<0.05)$. This finding supports the hypothesis that internal communication has a significant effect on employee performance. This means that the better the Ministry of Defense develops employee internal communication, the better the employee's performance will be. In other words, the higher the internal communication skills built by the Ministry of Defense, the performance of employees in carrying out their respective duties will also increase and the better. The quality and ability of internal communication is one of the fundamental factors for management and is a factor needed for the achievement of employee and organizational performance. The finding is in line with previous research which has proven that internal communication has a significant effect on employee performance.

\section{Conclusions}

This study primarily aims to investigate the effect of training, motivation, and work ethic factors on internal 
communication, and its implications for employee performance. Research findings indicate that individual training, motivation, and work ethic have a significant direct effect on internal communication. In addition, it was found that individual motivation had a significant direct effect on employee performance, while training and work ethics did not have a significant direct effect on employee performance. Internal communication has a significant influence on employee performance. Furthermore, it was found that internal communication was able to mediate the effects of training, motivation, and work ethics on employee performance.

The results revealed that the training, motivation, and work ethic factors had a significant influence on internal communication and employee performance. The results of this study have a number of managerial implications as follows. Training is one factor that supports the success of Department of Defense employees. Training can create an atmosphere of effective communication, although the direct effect of training on employee performance is not significant. Therefore, along with organizational changes and challenges more quickly, the organization needs to conduct training for its employees. Although this research does not have a significant effect on employee performance, the Ministry of Defense must strive to organize training programs. Motivation is the second factor thought to influence the success of the Ministry of Defense employees. It was found that motivation can promote the creation of effective communication and to improve employee performance. Therefore, the Ministry of Defense needs to increase the motivation of its employees. Work ethics is an important factor for the success of Ministry of Defense employees, because it can improve effective communication skills. Thus, the Ministry of Defense is required to grow and maintain the work ethic of its employees. The Ministry of Defense needs to foster and maintain a work ethic to build the characteristics and spirit of employee values, and also to create attitudes, personalities, and aspirations, so that it becomes a guiding instrument for maintaining communication, whether individually, in groups, or organizations.

\section{References}

Armstrong, M. and Baron, A. (1998), “Performance Management” London, Institute of Personal and Development

Aguinis, H. and Kreiger, K. (2009), "Benefits of Training and Development for Individuals and Teams, Organizations and Society” Annual Reviews Further 2009, 60: 451-74

Bahaudin, T. (2000) “Brainware Management: Generasi Kelima Manajemen Manusia” Penerbit PT. Elek Media Komputindo

Berkema, et al., (2000) "Management Challenges in a New Time” Academic of Management Review, Vol. 19 No. 3 pp 471-482.

Bavee, C. and Thill, J.V. (2000) "Business Communication Today”, Fifth Edition, New Jersey, Prentice Hall

Buckley, R. and Caple, J. (2009), "Theory and Pracrice of Training” London, Kogan Page. Ica

Curtis, D.B., Floyd, J.J., and Winsur, J.L. (2000) “Komunikasi Bisnis dan Profesional” Edisi Bahasa Indonesia, Bandung, PT. Remaja Rosdakarya.

Guerra, D. (2008) "Superperformance: A New Theory for Optimization”, Perfoemance Improvement”, Vol. 47 No. 5, pp 8-14

Kasali, R. (2009) “MYELIN Motivasi Intangables Menjadi Kekuatan Perubahan” Jakarta, Gramedia Pustaka Utama.

Kalla, H. (2005), "Integrated internal communications: a multidisciplinary perspective", Corporate Communications: An International Journal, Vol. 10 No. 4, pp. 302-314

Kickpatricks, D.L. (2006) “Evaluating Training Programs: The Four Levels” San Fransisco, Accessible, Pbublishing System, Ltd

Kumar, N. and Rosse, R.C. (2010) "Examining The Link Between Islamic Work Ethic and Innovation Capability" Journal of Management Development, 29(1) p. 79-93

Mubarok, E.S. and Putra, H. (2018) “The Influence of Training, Compotence, and Motivation on Employees Performance of Workers Social Scurity Agency In Banten Province, Indonesia” Journal of Economics and Suistuinable Development, Vol 9, No 4, 2018

Midhio, I.W. (2016), "Strategi Penggunaan Pendekatan Human Capital Dalam Mendukung Transformasi Sumber Daya Manusia Bidang Pertahanan Menghadapi Tantangan Masa Depan” Jurnal Wira Kemenham Volume 62 No. 46 September-Oktober.

Mathis, R.L. and Jackson, J.H. (2002) “Manajemen Sumber Daya Manusia” Edisi Bahasa Indonesia, Jakarta, Penerbit Salemba Empat.

Noe, R.A., et al., (2014), “Manajemen Sumber Daya Manusia: Mencapai Keunggunalan Bersaing” Edisi Bahawa Indonesia, Penerbit Salemba Empat, Jakarta.

Pace, R.W. dan Faules, D.F. (2000) "Komunikasi Organisasi:Bstrategi Meningkatkan

Rivai, V. dan Sagala, S. (2012) “Manajemen Sumber Daya Manusia Untuk Perusahaan” Penerbit PT. Raja Grafindo Persada Jakarta

Rothwell, W.J. dan Kazanas. H.C., (2003) “The Strategy Development of Talent: A Framewoek of Using Talent 
to Support Your Organization Strategy" Amherst, HRD Press

Robbins, S.T. (2003) "Perilaku Organisasi", Edisi Bahasa Indonesia, Penerbit PT. Index Jakarta

Snaks, A.M. and Haccoun, R. (2010), "Management Performance Through Training and Development" Amazon, CA

Sinamo, J. (2009), “Etos Kerja Dalam Bisnis”, Penerbit Institut Darma Mahardika, Jakarta 